\title{
Kelangsungan Hidup Larva Planula Acropora sp dalam Pemeliharaan Terkontrol Kepadatan yang Berbeda
}

\author{
Juniur Rangan ${ }^{1}$, Syafyudin Yusuf ${ }^{2 *}$, Esther Sanda Manapa ${ }^{2}$ \\ ${ }^{1}$ Mahasiswa Departemen Ilmu kelautan FIKP Unhas, \\ ${ }^{2}$ Dosen Departemen Ilmu Kelautan FIKP Unhas \\ s.yusuf69@gmail.com
}

\begin{abstract}
The survival of coral larvae as early phase of coral life is very important for their viability in environmen. This research aims to determine the survival of Acropora sp planula at different densities intensive nursery, and also to khow the critical survival time of them.. This research method was used experiment in density of larvae were held in control laboratory. The planula were rearing ini small container $200 \mathrm{ml}$ of water while the lavae density were used namely 0.5; 1.0, 1.5, 2.0 larvae / ml. The results indicated that survival rate for larvae of different densities $(0.5$ larvae/ml; 1.0 larvae/ml; 1.5 larvae/ml; 2.0 larvae/m) did not show any significant difference $(P>0.05)$. the highest survival rate of planula larvae was in the treatment with a density of 1.5 larvae/ml and the lowest from a density of 2.0 larvae/ml, and the most larval mortality was in the first 12 hours of rearing, due to the degree of adaptation of larvae to the rearing water medium in all treatment units, then death coral larvae decreased exponentially. This research will be very useful for efforts to restore coral reefs sexually, so as to reduce the impact of exploitation of coral seedlings which are often taken for asexual coral reef restoration as is often done throughout the world's coral reefs.
\end{abstract}

Keywords : Survival, Planula, Acropora, Sprmonde Indonesia

\section{PENDAHULUAN}

Siklus hidup karang keras (ordo Scleractinia), sama halnya dengan siklus pada berbagai hewan invertebrata dasar laut, dimana melewati fase planktonik. Fase hidup larva plaktonik sangat penting untuk pemeliharaan populasi dewasa dan sebaliknya sangat rentan terhadap perubahan lingkungan, predasi kompetisi dan penyakit. Kegagalan satu fase akan berdampak pada keberadaan populasi organisme (Levitan 2006; Markey et al., 2007; Gleason \& Hoffman, 2011). Reproduksi dan rekruitmen merupakan fase penting dalam perkembangan dan pemeliharaan populasi karang, sehingga salah satu strategi biologis pada karang adalah dengan melakukan reproduksi secara massal. Sekitar $85 \%$ reproduksi seksual karang dilakukan dengan cara melepaskan gamet di kolom air (broadcaster) sehingga fertilisasi gamet berlangsung di luar tubuh (Lasker 2006, Levitan et al., 1992). Dalam siklus hidup hewan karang, fertilisasi merupakan fase hidup yang sangat ringkas dan sebagai komponen yang sangat penting dalam evolusi organisme (Lasker 2006). Telur karang yang fertil berkembang menjadi stadia embrio (embryo stage), kemudian menjadi larva planula dan bermetamorfosis menjadi polip muda. Selama fase embrio 
dan larva planula sebagai planktonik terbawa oleh arus massa air menyebar ke berbagai lokasi hingga mengendap (Hayashibara et al., 1997, Schwarz et al., 1999, Portune et al., 2010, Gleason dan Hoffman, 2011). Karang genus Acropora di Kepulauan Spermonde memijahkan gonad pada fase bulan terang dan gelap (Yusuf, 2012; Malik, dkk, 2021), namun pada penelitian ini umumnya memijah pada fase bulan gelap. Selama perkembangan larva, terjadi penurunan jumlah larva akibat ketahanan tubuh larva sangat rentan terhadap kondisi kualitas air media pemeliharaan.

Setelah pembuahan, embrio karang membentuk larva yang berenang bebas setelah beberapa hari berkembang. Mulai dari fase pembelahan sel fertilisasi hingga planula yang akan mengendap di dasar perairan, larva membutuhkan waktu yang berbeda (Gleason dan Hoffmann, 2011). Selama perkembangannya, embrio mulai mengambang di permukaan air, tetapi mereka perlahan-lahan kehilangan daya apung karena simpanan lipid mereka digunakan dan mereka mulai berenang, membawanya ke dasar. Ini berarti ada teknik penanganan yang sedikit berbeda karena larva mengubah posisi di kolom air. Sangat sedikit penelitian mengenai larva karang keras. Waktu yang dibutuhkan embrio dan larva selama di kolom air disebut sebagai competence time. Competence time bagi setiap spesies karang tidak sama, hal ini disebabkan karena perbedaan spesies, competence time juga berbeda menurut model reproduksi dan posisi geografi. Secara umum, competence time bagi karang sekitar 48 jam di Jepang (Thamrin 2006), 95-104 jam jam khusus bagi Acropora spp di Australia (Yusuf. 2012), sementara waktu kompetensi Acropora spp di Kepulauan Spermonde belum diketahui secara pasti. Menurut Okubo dan Motokawa (2007), perkembangan embrio karang memperlihatkan kemiripan dengan embrio hewan lainnya pada bentuk pole, blastopole dan mulut.

Beberapa penelitian tentang kelangsungan hidup larva karang keras (Scleractinia) cukup lama untuk memberikan perkiraan umur panjang yang akurat. Selain itu, perubahan tingkat kematian selama hidup larva, yang diharapkan secara teoritis, memiliki implikasi terhadap tingkat konektivitas antar terumbu dan belum dihitung untuk spesies karang mana pun (Graham et al. 2008). Penelitian larva karang sangat dibutuhkan untuk melihat secara detail kelangsungan hidup karang mulai dari fase larva hingga fase juvenil (, karena fase tersebut sangat kritis dalam hidup karang. Jika larva berhasil menjadi juvenil, maka kemungkinan besar perbaikan ekosistem terumbu karang melalui reproduksi seksual karang akan mampu menjawab permasalahan kerusakan ekosistem terumbu karang saat ini. Penelitian ini bertujuan untuk mengetahui tingkat kelangsungan hidup dan titik kritis kematian larvae planula karang Acropora sp pada kepadatan pemeliharaan yang berbeda. Larva planula hasil pemijahan akan dapat digunakan sebagai stok untuk mencapai juvenile guna memenuhi kebutuhan rehabilitasi terumbu karang secara alami melalui proses reproduksi dan perkembangan larva karang Acropora.

\section{METODE PENELITIAN}

Penelitian ini berlangsung selama bulan Februari hingga April 2019 yang berlokasi di

Pulau Badi Kepulauan Spermonde Pangkep. Pada bulan Februari-maret merupakan waktu persiapan pemijahan karang dengan melakukan pengecekan gonad karang. untuk dilakukan pemijahan guna memperoleh larva planula dari karang yang memijah. Perlakuan eksperimen pemeliharaan larva dengan berbagai kepadatan yang berbeda dilaksanakan di Laboratorium Lingkungan Perairan Pusat Kegiatan Penelitian (PKP) Universitas Hasanuddin. 


\section{a. Tahap Persiapan}

Dalam tahap persiapan penelitian, dilakukan pemantauan kematangan gonad karang untuk memastikan puncak kematangan gonad pada masing-masing jenis karang Acropora. Pemantauan ini berlangsung dari bulan Februari hingga Maret, karena telah diketahui waktu puncak kematangan gonad karang sekitar bulan Februari dan Maret.Pemantauan ini dilakukan setiap dua kali dalam sebulan yakni pada bulan gelap atau awal bulan hijriah dan pada bulan purnama atau pada pertengahan bulan hjiriah.Karang yang telah dipantau (diberi tanda), kemudian ditandai lokasinya menggunakan GPS.
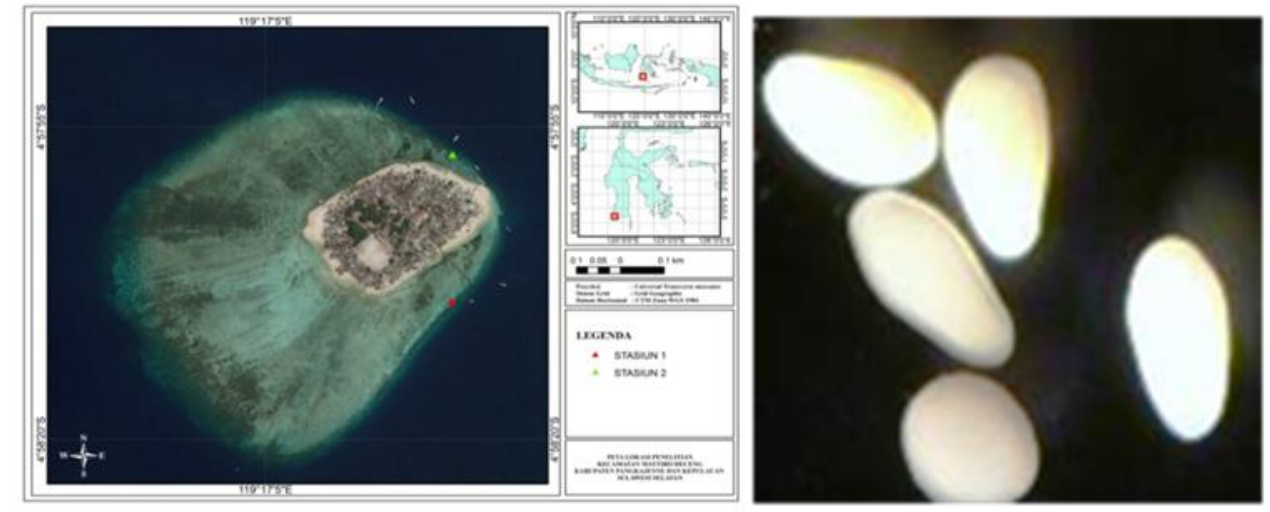

Gambar 1. Peta lokasi penelitian P. Badi Kepulauan Spermonde, Gambar 2. Larva planula hasil pemijahan buatan (Foto : S.Yusuf, 2011)

\section{b. Penanganan Pemijahan Karang}

Pada koloni karang Acropora yang telah ditandai kemudian diambil dan dipindahkan kedalam bak pemijahan volume 100 liter. Koloni karang dibiarkan dalam bak, sambil diberi aerasi lemah hingga koloni karang memijah. Setelah pemijahan, larva kemudian dipindahkan kedalam bak pemeliharaan larva. Selama proses perkembangan embrio sebelum mencapai fase larva, dilakukan transportasi dari Pulau Badi ke Marine Laboratorium Coral Center Puslitbang Laut, Pesisir dan Pulau Kecil LPPM Unhas. Setelah mencapai fase larva kemudian larva dipelihara dalam bak volume 10 liter untuk persediaan bahan uji.Pada umur larva sekitar 2 hari, larva dipisahkan dari stok larva, kemudian dipilih larva yang baik untuk bahan uji.

\section{c. Kondisi Larva Planula}

Hasil pengamatan mikroskop terhadap planula karang Acropora spp menunjukkan larva dalam kodisi sehat dengan bentuk yang sempurna, yakni berbentuk lonjong (seperti buah labu putih), larva planula yang digunakan dalam penelitian ini berumur 3 hari (50 jam) pasca fertilisasi (Gambar 2)

\section{d. Perlakuan Penelitian}

Setelah larva dipisahkan dari stok besar, larva kemudian dipindahkan kedalam wadah gelas plastik yang sudah dipersiapkan dan diatur tata letak berdasarkan acak sederhana sebanyak empat perlakuan kepadatan dan tiga kali pengulangan. Dari tiap unit penelitian kepadatan diamati kelangsungan hidup larva karang Acropora berdasarkan kepadatan larva karang yang berbeda. Perlakuan $\mathrm{P}$ kepadatan larva $=0,5$ larva $/ \mathrm{mL}$, Perlakuan $\mathrm{Q}=1,0$ larva $/ \mathrm{mL}, \mathrm{R}=1,5 \mathrm{larva} / \mathrm{mL}$, dan $\mathrm{S}=2$ larva/mL. Setiap wadah gelas plastik berisi air sebanyak $200 \mathrm{~mL}$ air laut. 


\section{e. Pengamatan Kelangsungan hidup Larva}

Kelangsungan hidup larva karang diamati dengan menghitung jumlah larva yang masih hidup dalam media pemeeliharaan. Dengan menggunakan pipet plastik, sampel air yang mengandung larva karang diambil tiap $1 \mathrm{ml}$ kemudian diletakkan dalam chamber plastic. Pengamatan larva dalam count chamber menggunakan lup kaca pembesar. Setiap unit perlakuan disampling 3 kali, kemudian dihitung rata-rata dari total larva. Pengamatan dilakukan dalm setiap 12 jam sekali pagi dan sore. Pengamatan pagi untuk mengetahui kelangsungan hidup malam sebelumnya, dan pengamatan sore untuk mengetahui kelangsungan hidup selama siang hari.

\section{f. Analisis Data}

Data penelitian kelangsungan hidup larva karang disajikan dalam bentuk persentase kelangsungan hidup dan data real jumlah larva setiap tahapan perhitungan. Pada akhir penelitian dianalisis menggunakan analisis Sidik Ragam atau ANOVA (Analysis of Variance). Data kelangsungan hidup larva setiap 12 jam yang diamati pagi dan sore dikonversi menjadi data harian. Selanjutnya untuk menjelaskan setiap tahapan dianalisis secara deskriptif.

\section{HASIL DAN PEMBAHASAN}

\section{a. Kelangsungan hidup Harian Larva Karang}

Kelangsungan hidup larva planula karang dipengaruhi oleh berbagai faktor, diantaranya adalah jumlah larva atau konsentrasinya di alam. Penelitian ini menggunakan variabel kepadatan larva dalam media pemeliharaan air laut. Perlakuan kepadatan yang digunakan dalam peneltian ini sebagaimana dijelaskan di metode penelitian adalah P 0,5 larva/ml, Q 1,0 larva/ml, R 1,5 larva/ml dan S 2,0 larva/ml. Dari empat perlakuan tersebut, selama tujuh hari pemeliharaan memperlihatkan kelangsungan hidup akhir larva yang berbeda dari masing-masing perlakuan (Gambar 3.A).

Grafik garis pada Gambar 3.A diatas menunjukkan prosentase kelangsungan hidup harian larva karang dari setiap perlakuan. Kelangsungan hidup larva planula harian pada perlakuan S (2,0 larva/ml) tercatat yang terrendah kelangsungan hidup mulai dari hari ke-2 hingga pada hari ke-7. Dari awal tebar dalam wadah larva planula sebanyak $100 \%$, kemudian secara drastis kelangsungan hidup menurun dengan tajam hingga $30 \%$ tercatat pada hari kedua, Walaupun pola yang sama kelangsungan hidup pada hari ke-2 berkurang dalam jumlah yang banyak, perlakuan $\mathrm{R}$ (1,5 larva/ml) masih memiliki kelangsungan hidup yang lebih tinggi dari yang lain. Selanjutnya semua perlakuan kepadatan larva dalam pemeliharaan terkontrol perlaahan berkurang hingga hari ke-7.

Pada akhir penelitian, pola kelangsungan hidup larva yang tidak linear menurut kepadatan rendah ke tinggi. Kelangsungan hidup larva planula di akhir penelitian tertinggi pada perlakuan kepadatan R (1,5/ml) dan berikutnya Q (1,0/ml). Perlakuan kepadatan P (0,5/ml) dan S (2,0/ml) lebih rendah kelangsungan hidupnya. Rendahnya jumlah kelangsungan hidup larva planula pada semua perlakuan karena diperkirakan rendahnya kemampuan adaptasi larva planula terhadap lingkungan hidup yang baru. Hasil penelitian ini sesuai yang diterapkan pada pemeliharaan telur kima (Tridacnidae) yang telah terbuahi kepadatan 2 telur per $\mathrm{mL}$. Larva veliger yang dipilih ditebar dalam takaran 1 telur per mL dalam rangka budidaya semi intensif (Braley, 1992). Perbedaan hasil akhir kelangsungan hidup larva karang hingga hari ke tujuh tidak secara linear mengikuti tingkat kepadatan larva yang dipelihara serta perlakuan. Hal ini disebabkan oleh berbagai faktor yang tak terduga. Salah satunya adalah karena larva kekurangan zooxanthella (Graham et al., 2008).

Dari hari ke hari, kelangsungan hidup larva karang terus menurun selama kurun waktu kompetens larva planula. Waktu kompetens larva planula adalah waktu dimana gonad karang 
mulai dilepaskan (spawning) hingga larva mengendap ke substrat (Agung, 2020 dan Yusuf, 2012). Penelitian ini mengamati kelangsungan hidup larva planula selama waktu kompetens harian tujuh hari (Gambar 3).

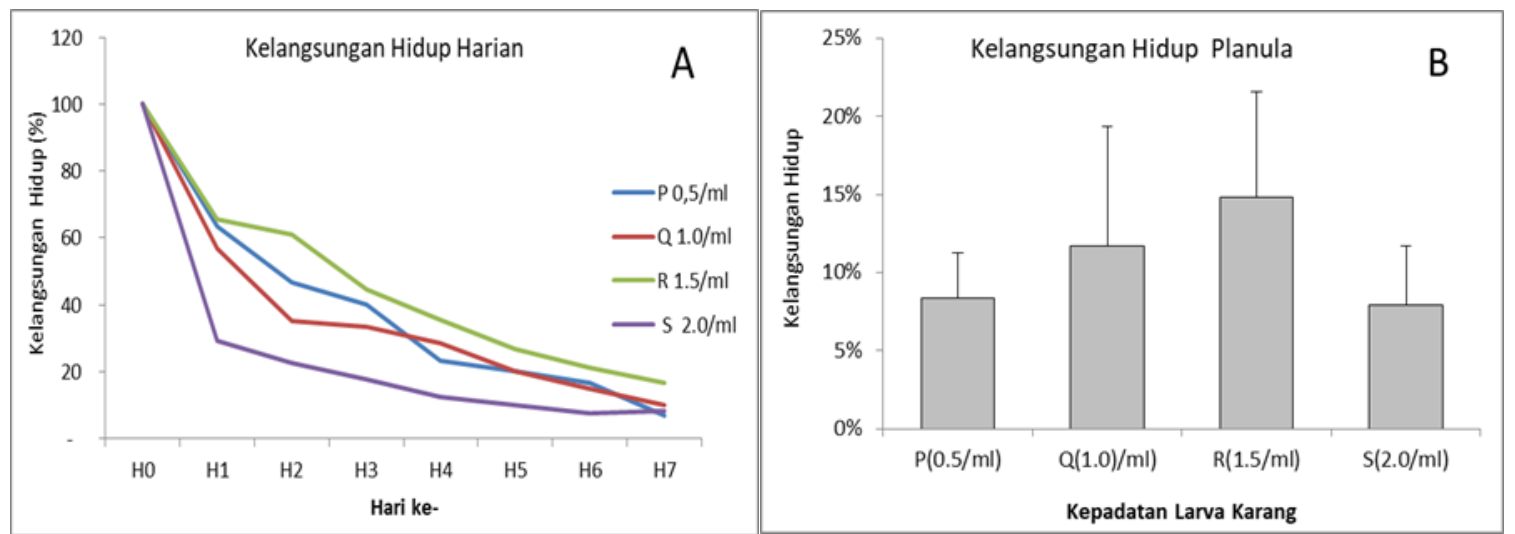

Gambar 3. A. Kelangsungan Hidup harian larva planula selama 7 hari Gambar 4. B. Kelangsungan Hidup akhir larva planula hari ke-7

\section{b. Kelangsungan hidup Akhir Larva Karang}

Hasil akhir dari penelitian ini (Gambar 4.B) menunjukkan bahwa kelangsungan hidup larva selama tujuh hari tertinggi dari perlakuan $\mathrm{R}(1,5 \mathrm{larva} / \mathrm{ml})$ yakni sebesar $19 \pm 7 \%$. Selanjutnya pada perlakuan Q (1,0 larva/ml) kelangsungan hidup larva $12 \pm 8 \%$ yang diikuti oleh perlakuan $\mathrm{P}$ $(0,5$ larva/ml $)$ dan $\mathrm{S}(2,0$ larva/ml) masing-masing sebesar $8 \pm 3 \%$ dan $8 \pm 4 \%$. Hasil analisis sidik ragam (ANOVA) menunjukkan bahwa tidak ada perbedaan kelangsungan hidup akhir antara perlakuan $(\mathrm{P}>0,05)$ artinya tidak terdapat perbedaan yang signifikan kelangsungan hidup larva pada salah satu perlakuan. Analisis lanjut menggunakan Tukey (Sig $=0,148$ ) sehingga tidak terdapat perbedaan yang signifikan. Dari keempat perlakuan tingkat kematian tertinggi terjadi pada hari pertama perlakuan dikarenakan jumlah kepadatan larva pada awal pengamatan yang tinggi pada media pengamatan sehingga tingkat kematian larva juga tinggi, dan tingkat kematian larva berkurang hingga akhir pengamatan.

\section{c. Piramida Kelangsungan hidup Planula Karang (Per 12 Jam)}

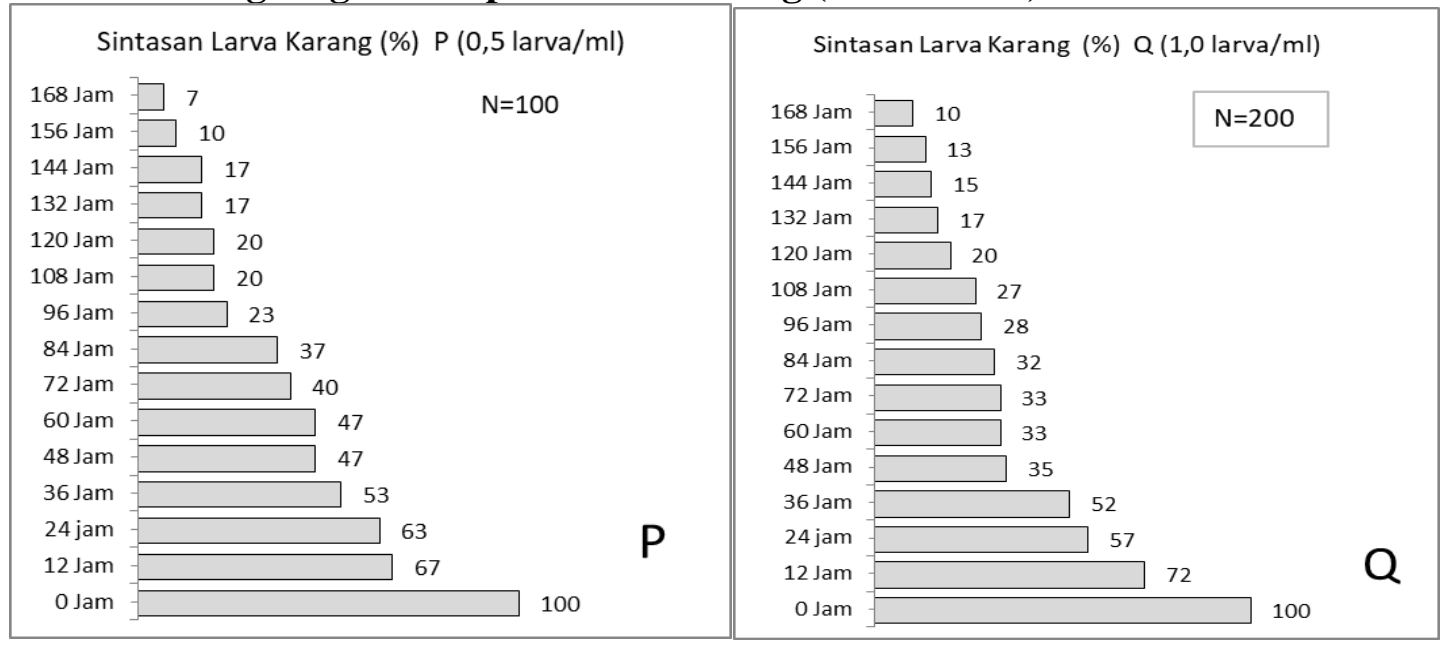




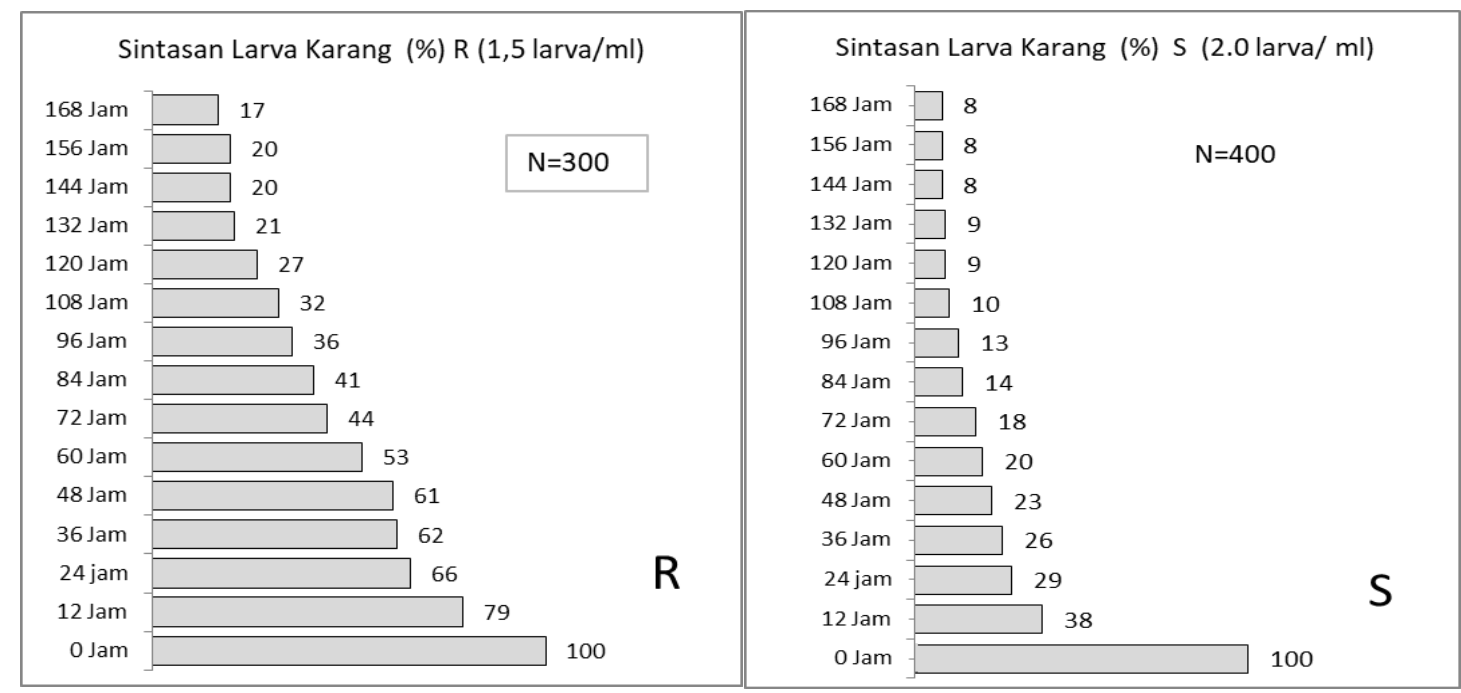

Gambar 5. Piramida Kelangsungan hidup Planula Karang (Per 12 Jam) Perlakuan P, Q, R, S.

Pada grafik piramida di atas, data kelangsungan hidup yang rendah menunjukkan kematian yang tinggi, dimana kematian larva yang terbesar dari larva hidup 100\% menjadi $67 \%$ pada perlakuan P dalam waktu 12 jam pertama. Selanjutnya pada waktu 96 jam kelangsungan hidup $37 \%$ menjadi $23 \%$, jumlah kelangsungan hidup larva planula dari waktu 24 jam sampai 72 jam dan dari waktu 96 jam ke 168 jam tidak terlalu signifikan. Pada perlakuan Q tingkat kelangsungan hidup terendah pada waktu 12 jam pertama dari $100 \%$ ke $72 \%$, dan dari $52 \%$ ke $35 \%$ pada waktu 48 jam sementara itu dari waktu 60 jam sampai 168 jam kelangsungan hidup larva melandai secara eksponensial Lonjakan kematian yang tinggi pada perlakuan Q terjadi pada hari pertama pengamatan.

Pada perlakuan R lonjakan kematian tertinggi dari $100 \%$ ke $79 \%$ pada waktu 12 jam, dan dari $79 \%$ ke $66 \%$ pada waktu 24 dimana hal tersebutsesuai data dinamika kelangsungan hidup larva bahwa perlakuan $\mathrm{R}$ terjadi kematian yang tinggi pada hari pertama pengamatan. Selanjutnya pada waktu 72 jam dan 132 jam terjadi penurunan jumlah larva yang cukup tinggi. Jika dibandingkan dengan perlakuan S lonjakan kematian tertinggi dari larva $100 \%$ menurun kelangsungan hidup menjadi 38\% pada waktu 12 jam pertama. Dari waktu 36 jam ke 168 jam jumlah kematian atau penurunan survival larva menurun secara eksponensial. Terjadinya tingkat kematian yang tinggi pada waktu awal pengamatan karena tingkat kepadatan yang tinggi bisa menyebabkan kompetisi ruang dan oksigen yang tinggi menyebabkan tingkat adaptasi larva yang rendah menyebabkan kematian yang tinggi.

Pada perlakuan S lonjakan kematian tertinggi dari yang hidup 100\% kelangsungan hidup menurun menjadi 38\% pada waktu 12 jam pertama. Dari waktu 36 jam ke 168 jam jumlah kematian atau penurunan (\%) survival larva telah menurun. Terjadinya tingkat kematian yang tinggi pada waktu awal pemeliharaan larva dalam kepdatan tinggi bisa menyebabkan kematian larva yang lebih tinggi karena tingkat adaptasi yang rendah hingga tingkat kompetisi yang rendah.

\section{KESIMPULAN}

Berdasarkan hasil dan pembahasan di atas, maka bisa disimpulkan bahwa tingkat kelangsungan hidup larva planula yang dipelihara secara terkontrol masih rendah antara 8-19\% dengan kelangsungan hidup tertinggi dari kepadatan 1,5 larva/ml dan terendah 2,0 larva/ml, namun tidak menunjukkan perbedaan nyata. Waktu kritis larva yang dipelihara dalam kepadatan 
0,$5 ; 1,0 ; 1,5$ dan 2,0 larva/ml terjadi pada hari pertama atau 12 jam pertama selanjutnya kematian larva berlangsung secara eksponensial hingga kurang dari 20 persen saat larva mengendap.

\section{UCAPAN TERIMA KASIH}

Terimakasih kepada lembaga Penelitian Sinica Taiwan yang telah memfasilitasi kegiatan lapangan memonitoring musim reproduksi karang Acropora spp melalui program kerjasama peneliti person to person Dr. Syafyudin Yusuf (Unhas) dengan Dr. Yoko Nozawa (Sinica Taiwan).

\section{DAFTAR PUSTAKA}

Braley, R.D.. 1992. The Giant Clam: Hatchery And Nursery Culture Manual. ACIAR Monograph 15. 144 pp.

COREMAP II. 2007. Pedoman Umum Pengelolaan Berbasis Masyarakat COREMAP. Ditjen Kelautan, Pesisir dan Pulau-pulau Kecil Departemen Kelautan dan Perikanan. Jakarta.

Gardiner, M.S. 1972. The Biology of Invertebrates. McGraw-Hill Book company. New York. Pp. 759-880

Gleason DF dan Hoffman DK, 2011. Coral larvae: from gametes to recruits. J. Exp. Mar. Bio. Eco. 408: 42-57.

Harison, P.L., R.C. Babcock., G.D. Bull., J.K. Oliver., C.C. Wallace., and B.L. Willis. 1984. Mass Spowning in Topical Reef Corals: Science 223: 1186-1189.

Harriot, V.J. 1983. Reproductive Ecology Of Four Scleractinian Species at Lizard Island. Great Barrier Reef. Bull : 2:9-18.

Harrison, P.L. and C.C Wallece, 1990. Reproduction, Dipersal, and Recruitment of Scleractinian Corals: In Dubinsky (ed). Coral Reefs: Ecosystems On The World 25. Elsevier. Amsterdam-Oxford, New York-Tokyo pp. 132-207.

Hayashibara T, Ohike S, Kakimuna Y. 1997. Embryonic And Larva Development And Planula Methamophosis Of Four Gamete Spawning Acropora (Anthozoa, Scleractinia). Proc.8th Int. Coral Reef Symp 2: 1231-1236.

Lasker HR. 2006. High Fertilization Succes In A Surface-Brooding Caribbean Gorgonian. Biol. Bull. 210: 10-17.

Levitan DR. 2006. The Relationship Between Egg Size And Fertilization Successin BroadcastSpawning Marine Invertebrates. Integrative and Comparative Biology 46(3) : 298-331.

Levitan, DR., Sewell, M. A., \& Chia, F. S. (1992). How Distribution And Abundance Influence Fertilization Success In The Sea Urchin Strongylocentotus Franciscanus. Ecology, 73(1), 248-254.

Markey KL, Baird AH, Humphrey C, Negri AP. 2007. Insecticides And A Fungicide Affect Multiple Coral Life Stages. Mar. Ecol. Prog. Ser. 330: 127-137.

Negri A P, Webster N S, Hill R T \& Hayward A J 2001 Metamorphosis of broadcast spawning corals in response to bacteria isolated from crustose algae Mar. Ecol. Prog. Ser. 223121131

Nontji, A. 1998. Laut Nusantara. Djambatan. Jakarta.

Nozawa Y, Tokeshi M and S. Nojima 2006 Reproduction And Recruitment Of Scleractinian Corals In A High-Latitude Coral Community, Amakusa, southwestern Japan Mar. Biol. 149 1047- 1058.

Nybakken, J.W. 1998. Biologi Laut: Suatu Pendekatan Ekologis. Penerbit : Gramedia. Jakarta.

Okubo N. dan Motokawa T. 2007. Embryogenesis Of The Reef Building Coral Acropora Spp. Zoo. Sci.24: 1169-1177. 
Portune KJ, Voolstra CR, Medina M, Szmant AM. 2010. Development And Heat Stress-Induced Transcriptomic Changes During Embryogenesis Of The Scleractinian Coral Acropora palmata. Marine Genomics 3:51-62.

Richmond R.H. and Hunter, C.L., 1990., Reproduction and Recruitment in corals, comparing among the Caribbean, the tropical pacific, and the Red Sea. Mar. Ecol. Prog. Ser. Vol. 60: 185-203,

Richmond, R.H. 1985. Variations in the Population Biology of Poccillopora Damicorrnis Across the Pacific Ocean. Proc. .5th coral reef cong, Tahiti 6: 101-106.

Richmond, R.H. 1987. Energetic, Compettency, \& Long-Distance Dispersal of planula Larvae of the corals Pocillopora damicornis. Marine Biology 93: 527-533.

Richmond, R.H. 1990. Relationship Among Reproductive Mode, Biogeographic Patterns And Evolution In Scleractinian Corals. Amsterdam. Elsevier; 317-322.

Richmond, R.H. 1997. Reproduction And Recruitment In Corals: Critical Links in Thepersistence of Reef. In Birkeland, C. (ed.). life and Death of Coral reefs. Chapmann \& Hall. PP 175197.

Richmond, R.H. \& Jockiel, P.L. 1984. Lunar Periodicity in Larva release in the Reef Coral Pocillopora damicornis At Enewetak and Hawaii.

Rinkefich, B. and Loya, Y. 1979. The Reproduction of the Red Sea Coral Stylophora pistillata. Gonad and Planuale. Mar. Ecol. Prog. Ser. 1: 133-144.

Rudianto, M.E. 2007. Keindahan yang Belum Terjaga. COREMAP II. Jakarta.

Schwarz JA, Krupp DA, Weis VM. 1999. Late larva development and onset of symbiosis in the scleractinian coral Fungia scutaria. Biol. Bull. 196: 70-79.

Setiono. H. 1996. Kamus Oseanografi. Gajah mada University Press. Yogyakarta.

Sorokin, Yu. I. 1993. Coral Reef Ecology. Ecologycal Studies 102. Springer-Verlag. Berlin Heiderberg, Germany.

Syarifuddin. A. A. 2011. Study Kelangsungan Hidup dan Pertumbuhan Karang Acropora formosa (Veron \& Terrence,1979) Menggunakan Teknologi Biorock Di Pulau Barrang Lompo Kota Makassar. Skripsi S1. FIKP Universitas Hasanuddin. Makassar.

Szmant, A.M. 1986. Reproductive Ecology of Pocciloporid Corals. Montrastrea annularis and M. carnosa. Mar.ecol prog.ser. 74: 13-25.

Thamrin 2006. Karang: Biologi Reproduksi dan Ekologi. Minamandiri Press, Pekanbaru.

Veron, J.E.N. 1986. Corals of Australia and the Indo-Pacific. August. Robertson. Publish.

Wallace CC. 1999. Staghorn Corals of the World: A Revision of the Genus Acropora. CSIRO. Collingwood, Australia.

Yusuf. S, Zamani. N.P, Jompa. J. 2014. Perkembangan Larva Dalam Embriogenesis Karang Acropora Hasil Pemijahan Ex-situ. Torani, Jurnal Ilmu Kelautan dan Perikanan Vol.24(2).

Yusuf. S 2012. Reproduksi Seksual Karang (Ordo Scleractinian): Pemijahan, Perkembangan Larva dan Metamorfosa. Disertasi Doktoral. Pasca Sarjana Institut Pertanian Bogor. 170 hal. 